\title{
From breaking the rule to making the rules: the adoption, entrenchment, and diffusion of gender quotas in France
}

Eléonore Lépinard*

Institut des Sciences Sociales, Centre en études genre, Université de Lausanne, Lausanne, Switzerland

(Received 7 January 2005; accepted 31 July 200®)

Once a country allergic to any type of preferential treatment or quota measure for women, France has become a country that applies gender quotas to regulate women's presence and representation in politics, the business sector, public bodies, public administration, and even some civil society organizations. While research has concentrated on the adoption of electoral gender quotas in many countries and their international diffusion, few studies focus on explaining the successful diffusion of gender quotas from politics to other domains in the same country. This paper proposes to fill this gap by studying the particularly puzzling case of a country that at one point strongly opposed the adoption of gender quotas in politics, but, in less than a decade, transformed into one of the few countries applying gender quotas across several policy domains. This paper argues that the legal entrenchment of the parity principle, the institutionalization of parity in several successive women's policy agencies, and key players in these newly created agencies are mainly responsible for this unexpected development. The diffusion of gender quotas in France thus offers an illuminating example of under which conditions women's policy agencies can act autonomously to diffuse and impose a new tool for gender equality.

Keywords: women policy agency; support structure; electoral quotas; corporate boards quotas; public bodies quotas

\section{Introduction}

Once a country allergic to any policy that would look like affirmative action for women or any other social group, let alone quotas with fixed targets, ${ }^{1}$ France has transformed in a decade and a half (1999-2014) into the land of gender quotas. Since the adoption of the last round of gender equality measures under the socialist government and parliamentary majority, ${ }^{2}$ gender quotas are now implemented in universities' juries, for hospitals' and other public institutions' higher civil servant categories, ministries' staffs, corporate boards of medium and large firms, supervisory boards of public institutions, professional organizations, sports federations, regional socio-economic councils and, last but not least, most elected political bodies. How has such a change been made possible?

When the debate on gender parity in politics appeared on the French public scene in the mid1990 s, the word "quota" itself was taboo. Activists went to great lengths to deny accusation of special treatment for women or of affirmative action ${ }^{3}$ and the very idea of a target to attain was dismissed as un-Republican, un-French, and contradictory with the principle of equality.

*Email: eleonore.lepinard@unil.ch 
Today, the picture is quite the opposite. In successive waves of legal reforms, the French Parliament has adopted numerous measures that use specific targets (in general a $40 \%$ quota) to impose women's presence in many decision-making bodies or functions that organize social, economic, and political life. This drastic reversal was not achieved without a fight. Many on the right wing of the political landscape, and some on the left-wing, as well as representatives of the business sector tried to resist the diffusion of gender-quota mechanisms in social and economic life in the mid2000s. However, the fight was more easily won this time around: the epic struggle for political parity that took place in 1999 and 2000 had definitely shaken and shifted the ground upon which political and social actors had to fight subsequently.

This paper retraces the process by which France has become one of the most gender-quotafriendly countries in Europe, and the factors that account for this unlikely outcome. I document how a concept once contentious in the French public sphere has become unproblematic and widely used to solve gender equality issues. Furthermore, I explore the factors that might account for this phenomenon. I show that the institutionalization of parity in several governmental and parliamentary bodies prevented backlash once the first parity reform was enacted, and further made possible the adoption and appropriation of the concept of parity/gender quotas by the French bureaucracy and political institutions and its subsequent diffusion to other policy domains. I argue that the rationales justifying parity, which triggered a normative shift about gender quotas, the legal entrenchment of gender quotas and the institutionalization of parity in the French governmental bureaucracy, created what I call, following Epp (1998), a support structure in favor of gender quotas. This support structure explains why gender quotas have become routinized - they are now presented as the preferred tool to address most issues relating to gender inequalities - and that their adoption in many fields of public policy has become endogenous rather than imposed by outside activist or international normative pressure. ${ }^{4}$

\section{Explaining entrenchment and diffusion of gender quotas across policy domains}

While a lot of scholarly attention has been focused on quota adoption and the factors that might prevent it or help it (e.g., Krook 2009; Meier 2012; Murray, Krook, and Opello 2012; see Praud 2012 for a review) or on gender quotas' impact (e.g., Franceschet and Piscopo 2008; Franceschet, Krook, and Piscopo 2011), less attention has been paid to the life quota legislations live after they are adopted and whether they are expanded, restricted or transformed (for an exception, see Meier 2014). However, with gender quotas now having been in place in many countries for more than two or three decades, and with no less than three major domains to which they apply - politics, economy/corporate sector and public bodies - the question of how quota legislations unfold, if and how they are translated and imported to other domains of public policy, draws attention to a new field of investigation and to other factors and processes than the ones that might have explained quota adoption in the first place.

Indeed, the literature on quota adoption has emphasized the role played by women's movements mobilizing for quotas and their ties with female politicians or insiders (Giraud and Jenson 2001; Baldez 2004; Scott 2005; Lépinard 2007; Krook 2009; Meier 2012), the importance of the political opportunity structure, including the support of left-wing political parties and governments and political competition among parties (Caul 2001; Meier 2004; Murray 2010), the influence of citizenship regimes and normative conceptions of equality (Krook, Lovenduski, and Squires 2006; Lépinard 2006; Meier 2012) and the instrumental role of transnational network and/or European and international institutions (Dauhpin and Praud 2002; Krook 2006; Bereni-2007). Hence, research on quota adoption tends to focus on the external pressure a coalition of actresses put on the political elite to adopt quotas and on the role that national allies - such as Courts or left-wing political parties - and international norms play in the 
process. However, while quota adoption tends to raise many normative debates in the public sphere and often attracts a lot of public attention, this might not be the case with quota diffusion to other policy domains. Moreover, while quota adoption might necessitate a constitutional revision, and therefore elicit legal controversy and opposition, quota diffusion to other policy domains might imply a much smoother process and less opposition from courts.

Hence, the study of quota entrenchment and diffusion can complement and nuance research on quota adoption. Entrenchment refers to the strengthening of the legal tools adopted to implement quotas in electoral politics (placement mandates, higher fines, constitutional revisions to legalize quotas), whereas diffusion refers to the adoption of gender-quota mechanisms in other spheres than electoral politics. Although the legislature must adopt each new gender quota, I use the term diffusion rather than use adoption, because, as the time lapse between each new adoption suggests, a mechanism of diffusion and processes of learning are at stake.

Despite the fact that scholars have noted the diffusion of quotas to various policy domains, even identifying a sequence specific to Nordic countries with three "generations" of quotas - electoral, public bodies quotas, and corporate sector quotas (Holli 2011) - and have suggested that gender quotas adopted in different domains tend to share similar rationales and follow a similar logic as the experience gained in one domain of public policy is exported to a new domain with increased legitimacy (see Meier 2014 on Belgium), little attention has so far been devoted to analyze the factors, the mechanisms, and the entrepreneurs of quota diffusion. The analysis of the French case proposed here aims at further exploring quota entrenchment and diffusion across domains using insights from three strands in current research: the literature on policy transfer and diffusion, and the literature on women policy agencies (WPAs).

The now vast literature on policy transfer (e.g., Dolowitz and Marsh 1996, 2000) and policy diffusion (see Maggetti and Gilardi 2015 for a review) focuses on the complex political dynamics by which elements of public policies are transferred between units; or, as analysts of diffusion put it, how the policies of one unit are influenced by the policies of other units (Gilardi 2010). Mechanisms identified by the diffusion literature focus on the behavior of actors understood as freestanding individual units with rational motivations (learning, emulation, or competition) which drive diffusion, whereas the older literature on policy transfer tended to insist more on institutions and public policy mechanisms. From the literature on policy transfer, I retain two main insights for the analysis of gender quotas diffusion: the role of policy entrepreneurs in transferring knowledge and policy tools, and the identification of factors enabling transfer such as the simplicity of the policy tool, its direct relationship to the problem to be solved and its predictability in terms of outcomes (Dolowitz and Marsh 1996). Indeed, as will become evident in the following sections, key actors contributing to diffusing quotas from the political realm to the economic and social spheres and the perceived simplicity, efficacy, and predictability of gender quotas have made them preferred tools for feminist policy-makers.

The literature on WPAs provides yet another insight to study quota diffusion. Indeed, the literature on state feminism underscores how WPAs might relay women's movements' claims, thereby gendering public policy debates and outcomes (e.g., Stetson and Mazur 1995, 2000; Lovenduski 2005). It is therefore important to incorporate into the analysis the role of state institutions (Franceschet and Piscopo 2013; Piscopo 2015), especially at the stage of entrenchment and policy diffusion. Indeed, at this stage, WPAs might act more autonomously, and may be much more instrumental in getting new legislation passed without external activists' support. For example, research on WPAs suggests that for policy domains that are well institutionalized with permanent networks and institutions inside the state, WPAs constitute a crucial actor to prevent backlash and preserve feminist gains in times of retrenchment (McBride and Mazur 2010). Gender-quota diffusion in France therefore offers a particularly interesting case to explore the autonomous role WPAs might play in shaping public policy. In particular, as 
I show in the next sections, the institutionalization of the parity claim in successive governmental bodies dedicated to gender equality or parity was instrumental in helping to prevent backlash against parity in electoral politics and in supporting the diffusion of gender quotas to other domains. I argue that these WPAs dedicated to supporting the entrenchment of parity were all the more successful in their task, because the principle of parity was constitutionally enshrined, providing an important legal tool to reframe demands for gender equality. Taken together, the legal provisions entrenching parity and the WPAs in charge of monitoring its implementation constitute what Charles Epp, in his analysis of the "rights revolution" (Epp 1998) has called a "support structure" enabling the entrenchment and the diffusion of gender quotas.

This analysis is based on extensive qualitative fieldwork: complete analysis of all the parliamentary and constitutional debates and parliamentary reports involving gender quota measures between 1982 and 2014 which cover electoral quotas, corporate board quotas (CBQs), public administration quotas, and public bodies quotas; reports from WPAs on gender quotas during the same period issued by the Observatory of Parity, the parliamentary delegations for women's rights, and the High Council for equality between women and men; and seven semidirective interviews with key players in WPAs and NGOs in favor of parity made in June 2014.

\section{Breaking the rules, shifting the normative and legal ground: adopting electoral parity}

The story of gender quotas in France goes back several decades and is full of unexpected developments, surprising twists, and epic battles. However, what is striking is that since 1982, when the first gender quota bill was introduced, the normative, legal, and political grounds upon which social and political actors debate this issue has radically shifted. The initial deeply rooted resistance to quotas expressed by the political and judicial elite and constitutional judges has faded away. Highly principled arguments against quotas, invoking the indivisibility of the Republic and the legal definition of equality and democratic freedom have disappeared and left room for more pragmatic assessments about the need to improve women's presence in decision-making bodies in all spheres of social life. In this section, I retrace briefly the history of quota adoption in France and I document the normative, legal, and political shift that has occurred as new gender quota provisions have become legitimized and much more easily adopted - even under right-wing legislature - than when parity first appeared on the French political scene.

The history of the adoption of electoral gender quotas in France is now well documented (Bereni and Lépinard 2004; Baudino 2005; Scott 2005; Opello 2006; Rosenblum 2006; Lépinard 2007; Krook 2009; Murray 2010). The initial 1982 decision of the French Constitutional Council to declare unconstitutional the provision of a bill proposing a $25 \%$ quota of women on candidate lists for municipal elections ${ }^{5}$ framed the subsequent public debate on this issue for two decades. Indeed, the Constitutional Council (hereafter CC) argued its refusal of gender quotas on highly principled grounds invoking two constitutional principles: the indivisibility of the sovereignty of the people and the equality principle. The use of a quota was perceived as dividing the people into different groups (men and women) and therefore incompatible with the idea that the French people is undividable and exercises its sovereignty through its representatives in a non-divided way. Second, the quota was perceived as contradicting the principle of (formal) equality that applies to candidates for elections. When the debate resurfaced in the beginning of the 1990s, in part, thanks to a European network of experts on gender balance in decisionmaking and the influence of international norms following the Beijing conference, French parity activists faced tremendous opposition. However, and surprisingly for many observers, this strong opposition from the power elite and the $\mathrm{CC}$ was overcome after a decade of activism. The context and factors that helped reverse the situation are now well known; ${ }^{6}$ it is sufficient to note here that when the socialist Party unexpectedly came back to power in 1997, the moment was 
finally ripe for a revision of the Constitution in order to unlock the 15-years long constitutional freeze on quotas. The presence of a left-wing majority in the Assembly and the support of the Senate president, Christian Poncelet, combined with the personal support of the Prime Minister Lionel Jospin to the cause meant that a constitutional revision, which requires a majority of three-fifth of both chambers, could pass, which it did quite unanimously.

What was gained from the constitutional revision? Article 3 of the Constitution was changed to include the following sentence: " "the law promotes women's and men's equal access to electoral mandates and elective functions." The placement of this sentence in Article 3, that defines national sovereignty, is a direct consequence of, and a direct response to, the framing of the debate by the CC in terms of sovereignty. A revision to Article 4 adds that political parties must contribute to this objective. In 2000, several laws defined more precisely the parameters of the implementation of this new constitutional principle. ${ }^{8}$ The debate was, again, heated in the Parliament, testifying that despite the symbolic constitutional victory, resistance to quotas was still active from both the right- and the left-wing of the political spectrum (Lépinard 2007). ${ }^{9}$

The dominant narrative of the 1999 constitutional reform is one of breaking the rule against quotas and trying to impose a new one: the parity principle. Indeed, like in other countries such as Portugal or Italy where a constitutional change was necessary to adopt gender quotas, opposition to parity, in line with the CC 1982 decision, was voiced in the name of preserving the integrity of the constitutional principle of equality (Rodriguez Ruiz and Rubio Marin 2008). This opposition on normative and legal grounds encouraged parity activists to place their claim on high normative grounds as well. Whereas in international texts, gender quotas are defined as temporary special measures and exceptions to the legal norm of formal equality, French parity was always framed as a normative principle with no term limit (Rosenblum 2006; Lépinard 2007, 2013).

Moreover, although the focus had been clearly to "improve" and "perfect" French democracy by adding to it the principle of parity, this principle could be expanded outside the realm of politics to other decision-making bodies as pioneer parity activist Gisèle Halimi noted early on (Halimi 1998). In fact, parity represented an opportunity to reframe demands for gender equality, to claim new measures for women's rights. Hence, parity introduced both a legal change, as positive action measure for women were for the first time constitutionally legitimized, and a semantic change, from equality to parity which actually opened up new venues to elaborate new claims. At the end of a decade of intense activism, the adoption of parity operated a shift in the normative and legal ground of the debate on gender quotas in France. This first component of a support structure in favor of gender quotas - a new legal provision, a discursive innovation - was complemented by the creation of WPAs devoted to the promotion and monitoring of parity, to which I now turn.

\section{Entrenching parity inside institutions}

In the decade following the victorious campaign for the constitutional revision, the principle of parity became a new way to frame demands for equality, and was more clearly adopted by femocrats and French WPAs as a part of their toolkit or "grammar" for action (Bereni and Revillard 2007). I argue that this adoption of the parity motto was made possible by the creation of a strong support structure (Epp 1998) in favor of parity and by the political activism of key players in that structure. Indeed, in the 1990s, the WPAs already in place in the French central administration (the Service des droits des femmes, $\mathrm{SDFE}^{10}$ ) did not take a stand on the parity issue, which seemed to fall outside of the scope of their mandate, traditionally focused on themes such as equal pay or violence against women (Baudino 2005; Bereni and Revillard 2007). However, the creation of the Observatory of Parity changed the institutional landscape of WPAs in France. 
In 1995, parity activists asked presidential candidates to take position on the parity issue during the presidential campaign. The vast majority of candidates, eager not to lose women's votes, took a positive stance on the issue. This led the newly elected president, Jacques Chirac, from right-wing party RPR, to create as a token of good faith and follow-up on his promise made for the Beijing UN conference on women, a small governmental institution: the Observatory of Parity (Observatoire de la parité), mandated to give expertise and advice on this topic to the government. Key female politicians and feminist activists appointed in 1995 by the right-wing government to the newly created Observatory of Parity helped keep the debate alive and produced the first official report devoted to the issue of parity in 1996 (Halimi 1998). While for the first two years the Observatory was first and foremost a platform for the parity movement, collecting data on gender gaps and developing pro-parity arguments and disseminating them to parliamentarians, in 1997, its powers were extended to give recommendation on potential bills and legislative reforms to improve women's presence in decision-making (Baudino 2005).

Once the parity laws were passed, the Observatory became the official monitoring body for the implementation of the laws, compiling data and producing expertise after each round of elections on how to improve the laws and their implementation. During the first half of the $2000 \mathrm{~s}$, this new support structure, the Observatory and the legislative delegations for women's rights created in 1999, helped reduce backlash against the 2000 law and deepen its reach in the political domain and beyond. For example, the right-wing majority passed electoral reforms in 2003, with the direct effect of reducing the scope of the parity laws for senatorial, regional and European elections. Indeed, while deputies introduced a strict "zipper" system for candidate lists for senators elected with a proportional representation system, electoral reforms reduced the number of senators elected with such a system. ${ }^{11}$ Similarly, the government and its parliamentary majority introduced smaller districts for both European and regional elections, with the predictable effect of limiting the impact of the parity requirement. ${ }^{12}$

However, parity activists inside political institutions did not witness those attempts to curb the parity reform and its disappointing implementation for the National Assembly (elected with a uninominal system) without taking action. Quite the contrary, under the tenure of Marie-Jo Zimmermann - a right-wing MP close to President Chirac - from 2002 to 2009, and despite a right-wing majority in both chambers, the Observatory helped craft several pieces of legislation to improve the efficacy of the parity laws. In 2003, the placement mandate was tightened with a zipper system (instead of three women every six candidates) for all proportional elections. In 2007, a law to promote women and men's equal access to electoral mandate and elective functions ${ }^{13}$ was passed. It extended parity to executive functions in regional and municipal councils (in cities over 3500 inhabitants) and increased the financial penalty for political parties that would not apply parity for legislative elections. Finally, this law also imposed a "mix ticket" for uninominal elections (legislative and cantonales): the substitute should be of the opposite sex of the candidate. Others bills were also proposed to improve the implementation of parity. For example on 20 May 2010, then-General Rapporteur of the Observatory, Chantal Brunel, proposed a bill (no. 2529) to "promote women's and men's equal access to electoral mandates with a uninominal majoritarian mode of election." These failed attempts testify to the continuing activism on the issue of political parity inside governmental and legislative institutions devoted to parity.

Another interesting way in which the Observatory of Parity tried to prevent setbacks in the implementation of the parity laws was by providing prospective knowledge on how certain changes in the electoral system would adversely affect the representation of women. For example, when Nicolas Sarkozy, then-President of the Republic, proposed a bill in 2011 to suppress two important local elective mandates (local counselors and regional counselors) and blend them into only one mandate of "territorial counselors" mostly elected through uninominal majority system (rather than proportional list system), the Observatory provided an assessment 
of the number of women that would probably be elected under such a new electoral system, showing how women's presence would drastically decrease. It provided these numbers for each French department, comparing each time with the current number of elected women. ${ }^{14}$

During all these legislative processes, the support structure institutionalizing parity was a key actor first, thanks to its expertise: gathering data, issuing reports on how parity was implemented and pointing to loopholes and problems in the current legislation. ${ }^{15} \mathrm{~A}$ second important feature was that members of the Observatory were also MPs and networked with other WPAs to create momentum during electoral reforms. The fact that Marie-Jo Zimmermann headed both the Observatory and the National Assembly delegation for women's rights from 2002 to 2009 also enabled a close working relationship and a relaying of the Observatory's concerns in the legislative arena. While activist networks such as Elles Aussi continued to lobby, to issue press releases, to organize conferences and training sessions for female representatives, their impact on the public debate and on the legislative process was minimal compared to the impact of the expertise, lobby and networking from the Observatory and its key players.

As the socialists came back to power in 2012, some electoral reforms long called for by parity activists finally took shape and electoral parity was further entrenched in the French political system. In 2013, an electoral law ${ }^{16}$ changed the way local counselors (conseillers départemen$\operatorname{taux}$ ) are elected in order to impose parity. It introduced a real "mix ticket": one man/one woman on the ballot, both candidates, and coupled circumscriptions together in order to maintain the same number of representatives. This electoral reform also aligned cities over 1000 inhabitants on the same mode of election as cities over 3500 inhabitants (a proportional list system, allowing a strict parity to be applied to candidate lists). Parity was also applied to EPCIs (établissements publics de cooperation intercommunale), an important type of indirectly elected local political institution reuniting several cities that had been so far left out of the scope of the parity reform that local power, and local men, had relocated there (Lépinard 2006). Then, another electoral law re-introduced a proportional list system to elect senators in districts with three or more senators. ${ }^{17}$ Finally, in 2014, an important piece of legislation tightened the condition for elected representatives to hold several mandates at the same time, thereby opening new positions in the political system. ${ }^{18}$

All in all, reforms asked for by parity activists during this period were swiftly adopted and setbacks inflicted under right-wing government were finally overturned. Despite the fact that the process was not linear and that resistance was always present, especially when the right was in power, the incremental process of entrenching and expanding parity - improving its reach and efficiency - from within institutions is quite similar to what has been observed in many Latin American countries (Piscopo 2015).

\section{Endogenization and diffusion: quotas for corporate boards}

The parity motto emerged as French feminist activists networked at the European level and produced expertise on women's participation in decision-making that proved to be crucial in their national crusade. This typical boomerang effect (Keck and Sikkink 1998) and important activist mobilization characterized the early 1990 s and the emergence of the parity claim but did not last beyond this first phase. Instead, the parity claim and the idea of gender quotas as tools to reach equality developed, thanks to the institutional support structure, and generated new venues and new advances, with fewer references to and no support from international or European institutions and only weak civil society mobilization. Diffusion from politics to other domains therefore appears as a process endogenous to institutions in which WPAs play a central role.

The Observatory of Parity was a key player in the support structure that helped to diffuse gender quotas beyond electoral politics, thanks to two important institutional features. First, 
the fact that members of the Observatory also held positions in other ministries or in the SDFE meant that they could transfer the tool of gender quotas as the best means to redress inequalities to other spheres. The fact than many members were also MPs meant that they could launch the debate and present initiatives at the parliamentary level if necessary (Ressot 2013, 186). ${ }^{19}$ Second, the fact that the Observatory's mission was not confined to politics but included from 1998 onwards $^{20}$ a larger mandate made it a legitimate institution to intervene in debates on pension reform, violence against women or quotas in public service (Ressot 2013). As Catherine Génisson, Generale Rapporteure of the Observatory from 1999 to 2002 stated in the 2002 Observatory's report: "the parity law is a major law, it is meant to develop in the whole society a parity culture, in politics but also in other domains, in particular in the social and economic spheres." This diffusion of the parity agenda was made possible, in part, thanks to the Observatory's members' networks in other institutions. For example, members of the Observatory's council Françoise Milewski and Annie Junter participated in the Committee in charge of gender equality in the public administration headed by Anicet LePors in 2002. As the title of the second report issued in 2003 by the commission on women's access to management positions in the public service, "Promoting the parity logic," 21 suggests members of the Observatory transferred to this new field of public policy the idea that gender quotas should also be used to promote women's access to top positions in public service.

The story of the push for CBQs, and of their adoption in 2011, brings evidence of the process by which gender quotas were diffused, thanks to the support structure, to the economic sphere. Although the debate on CBQ existed in other European countries at the time (Oliveira and Gondek 2014) both the inspiration for the bill and the process to adopt it are endogenous to French institutions rather than a foreign import. While the Norwegian CBQ logically appears as an example in some parliamentary reports, ${ }^{22}$ these references do not amount to a policy transfer: no expert network was mobilized, no clear transfer of expertise was realized beyond one short visit to Norway by Marie-Jo Zimmermann. Besides, organizations concerned with political parity did not mobilize on the CBQ legal reforms. Only after the law passed did organizations of women's accountants or women's board members (such as the $\mathrm{AFECA}^{23}$ ) develop and launch networking initiatives with academics in business schools and training for women's board members. Finally, the development of antidiscrimination legislation in the 2000 s and the rise of diversity discourse in the private sector did not put CBQ on the political agenda. Quite the contrary, the diversity charter adopted in 2004, and the various private initiatives developed in the 2000s were based on voluntary actions and never proposed a constraining CBQ as one of the tools to improve diversity (Bereni 2009). If diversity appears today as a rationale used by actors in the private sector to legitimize $\mathrm{CBQ}$, it is a retrospective rationale to accommodate a measure once perceived as a governmental intrusion in businesses' freedom to nominate whomever they want as board members.

Hence, the policy impetus for CBQ came from inside the support structure, in particular in the person of Marie-Jo Zimmermann, as General Rapporteur of the Observatory of Parity and of the National Assembly's delegation for women's rights. Aside from her one-day fieldtrip to Norway, the process of adoption of CBQ does not involve networking across Europe (as political parity did) or references to European or international soft law or incentive. As she stated herself in an interview:

Q: Did you benefit from any European influence?

M-J Z: No, absolutely not. I had as my ambition that France should be the model. ${ }^{24}$

In 2005, the then-Minister for parity and gender equality at work, Nicole Ameline, proposed a 
women's presence on boards and the need to reach a gender balance within a five-year period, but did not say how this was to be accomplished. Marie-Jo Zimmermann proposed several amendments to the bill to include a limit of $80 \%$ of members of the same sex on corporate boards as well as on commissions representing workers in the public sector and supervisory boards of public institutions. The gender gap was to be reduced within 5 years, however the bill and the law finally adopted (including Zimmermann's 20\% quotas) did not define any sanction for non-compliance. Despite an agreement reached in the National Assembly and the Senate on the use of a $20 \%$ quota, ${ }^{26}$ the $\mathrm{CC}$ struck down the quota provision. Indeed, 60 deputies referred the law to the $\mathrm{CC}$ on procedural grounds (they did not mention the quota provision), but the CC decided to examine the quota provision on its own initiative and, unsurprisingly given its historical commitment against quotas, struck down the provision using a narrow interpretation of the 1999 constitutional amendment that excluded from its scope non-political elected functions and mandates. ${ }^{27}$ Mobilization from within the WPA, in this case, in particular, the Observatory, thus met with resistance from another institution, the $\mathrm{CC}$ in charge of the legal entrenchment and legitimization of gender quotas.

A constitutional reform was, once again, needed to implement gender quotas. The 2008 constitutional revision planned by President Sarkozy to modernize political institutions gave MarieJo Zimmermann the window of opportunity she was looking for. Advised by an important figure of her own party, Simone Veil, ${ }^{28}$ and despite Sarkozy's opposition, Marie-Jo Zimmermann proposed an amendment to Article 3 to enlarge the constitutional commitment to promoting women's equal access to electoral mandate to "professional functions." However, the fight was not so easy to win. Indeed, she was going against her own political party since the President, under pressure from organized business representatives, had decided he did not want any constitutional revision on the CBQ issue and wanted rather to add a provision on gender equality in the Preamble of the constitution (therefore with no legally binding effect).

The battle for the constitutional revision, to add professional responsibilities to Article 3 of the Constitution, repeated the arguments already rehearsed in 1999 but in a minor mode. Opposition was now concentrated in the right-wing Senate and Marie-Jo Zimmermann, who witnessed the senate debate from the public gallery used "shaming" tactics with the press on her side to pressure senators to vote her amendment. ${ }^{29}$ Arguments already developed to oppose political parity in the name of a formal conception of equality were again brought out but with very little effect. The idea voiced by some senators that "only individuals are bearers of equal rights" and that "the Republic ignores groups that, by their nature, would introduce discrimination" 30 was replaced by more pragmatic arguments about the diversity in abilities and backgrounds women would bring to corporation. ${ }^{31}$

In the name of pragmatism, in the year following, the constitutional revision Marie-Jo Zimmermann along with Brigitte Grésy, former head of the SDFE and author of a report on equal pay in $2009,{ }^{32}$ proposed in the first bill proposal of what would became the 2011 CopéZimmermann CBQ law ${ }^{33}$ that parity be replaced by a $40 \%$ quota. $^{34}$ This shift shows that as gender quotas were diffused to the economic sphere the initial normative argument to entrench this new definition of equality in the legal order gave way to a more pragmatic assessment of quotas' efficiency as a tool in the gender equality policy toolbox, and testifies that the legal and normative grounds were indeed different in 2009 than a decade earlier.

The diffusion of gender quotas did not stop at corporate boards - a year later in 2012, the "loi Sauvadet" imposed a $40 \%$ public bodies gender quota (PBQ) for higher public service functions to be reached by 2018, thanks to the lobbying of two deputies, Françoise Guégot and Marie-Jo Zimmermann. This quota also applies to administrative and supervisory boards of public institutions, high councils, juries, and selection committees in public service procedures. ${ }^{35}$ Again, this process was top-down, endogenous to the Parliament and the executive bureaucracy, with 
scarce public debate on the quota measure, little publicity in the media, and no opposition to the quota scheme.

Hence, the 2011 CBQ law and the 2012 PBQ law, contrary to the electoral parity laws, are the results of a top-down process, in great part made possible by the support structure created as a response to the political activism of the 1990s for political parity. Their adoption testifies to the diffusion of the parity principle beyond electoral politics, and of the diffusion of a simple and efficient tool to implement it: gender quotas.

\section{Further institutionalization, diffusion, and routinization}

In 2013, with the left finally back to power, parity was further legally entrenched and diffused: one new law extended the parity principle to elected and nominated bodies in universities ${ }^{36}$ and two others deepened parity in electoral politics. ${ }^{37}$ Parity was also further institutionally entrenched. Socialist President François Hollande closed down the Observatory in order to create the Haut Conseil à l'égalité entre les femmes et les hommes, (High Council for Equality between women and men - HCEfh). Still a parallel structure to the administrative bureaucracy in charge of women's rights, the HCEfh has a broader mission and an extended staff ${ }^{38}$ compared to the previous Observatory. Among its members are high civil servants in charge of gender equality in each ministry, as a way to mainstream gender equality in the executive bureaucracy. Sanctioning the progressive enlargement of the Observatory's mission and policy interests that took place during the 2000 s, parity is now only one of the five policy fields covered by the HCEfh (along with gender stereotypes, international, health and reproductive rights, and gender violence). The HCEfh, like the other WPAs, has been charged with the mandate to provide impact studies on pieces of legislation with a gender dimension. ${ }^{39}$ It can also provide, upon request by the Prime Minister or the Minister in charge of women's rights, opinions on bills that are under scrutiny in the Parliament. ${ }^{40}$ This ex-ante procedure allows femocrats within the HCEfh to mainstream gender quotas in other domains by proposing amendments adding gender quotas. For example, as a consequence of the opinion released by the HCEfh, ${ }^{41}$ the 2013 law reforming higher education also included provisions to promote parity in university decision-making bodies and representative bodies. ${ }^{42}$

The HCEfh also delivered an impact study, prior to parliamentary discussions, on the 2014 bill on "real equality between women and men," "43 which devotes a whole section to "Generalizing the constitutional objective of parity." The law itself follows these incentives and addresses domains where parity should be implemented (or better implemented) in politics, such as legislative elections and in inter-communal structures, but mainly outside politics in the public domain, such as chambers of commerce, agriculture, and industry, as well as the private domain such as sports organizations. Finally, the HCEfh's opinion on the 2014 equality bill identifies other domains to which quotas and the parity principle could be applied in the future, such as unions, NGOs, and political parties. Hence, virtually every public or professional institution or organization has become a potential site of gender-quota implementation.

These proposals to disseminate gender-quota mechanisms way beyond politics or corporate boards did not meet any opposition, quite the contrary, parity and gender quotas seem to have become unproblematic. As the Secretary General of the HCEfh stated when asked about possible opposition to the idea of using gender quotas to reach equality:

Q: So numbered targets are now generalized? After so much resistance are they now accepted as a means to reach an objective?

A: In the political discourse the evolution during debates at the National Assembly is clear, for the last law nobody batted an eyelid (...) there is always some resistance in the 
Senate on quotas ... they say they agree with the concept of parity because anyway it has become politically incorrect to be against parity $(\ldots)$ but they always find ways to try to suppress quotas, but at the National Assembly ( ... ) it's now part of the tools. We used to hear that France is indivisible and all this discourse against positive discrimination, temporary special measures... and we don't hear that anymore, which is funny because it was legally very entrenched and now it's gone."

Echoing this statement, the term parity was recently included in the body of a legal text for the first time (and not in the exposé des motifs of the bill, i.e., the political rationale that precedes the legal text itself): the 2013 law on higher education mentions explicitly in several of its provisions the word parity. The same goes for the 2014 equality law, of which one of its titles reads "applying the constitutional principle of parity." This trend mirrors the political will of the HCEfh to see the parity principle more clearly defined and identified as a principle of equal sharing of power and of representation between men and women, a "common referential principle identifiable by all actors and adapted for each sector [of social and economic life]." 45 Once banned as un-republican, unFrench, and radically different from parity, quotas are now presented in a very different light by the HCEfh:

Quotas are legal and legitimate in the name of a coherent republican universalism. Quotas are not preferential measures but corrective and transformative measures that aim at undoing structural barriers, which are incompatible with the principle of equality. ${ }^{46}$

Quotas have thus been successfully diffused to almost all decision-making bodies in the economic sphere (CBQ and professional organizations), in the public sphere (public bodies from ministry to advisory boards, university juries, and hospital management), and in the social sphere (sport federations). This diffusion of gender quotas clearly bears the mark of the HCEfh and no trace of NGO activism or external influence from European institutions.

\section{Conclusion}

Once a measure depicted as a foreign import and hotly debated in the public sphere, gender quotas have become a legitimate and unproblematic means to redress gender imbalance, and consequently have receded to the margins of the public debate. The French case shows that the dynamics of gender quotas' diffusion differ from the dynamics of gender quotas' adoption in the political realm. The 1999-2000 reform was clearly the product of a wide mobilization, allying various women's organizations that had not previously been allied in any type of coalition, mobilizing female politicians and using norms and discourses from the European level. By contrast, the diffusion of gender quotas was made possible, thanks to the institutionalization of parity within various bureaucratic structures. The process of diffusion was mostly endogenous to French political institutions and much less controversial than the initial adoption of quotas. As quotas became a routinized tool, the left/right divide on this issue has tended to fade and opposition in parliamentary debates has become less and less vocal. The Senate and the CC have remained opposed to quotas. However, this lack of support did not prove unsurpassable: it delayed the adoption and diffusion process but still constitutional amendments and new legislations were passed under both right-wing and left-wing parliamentary majorities.

These differences between the phase of adoption and the phase of diffusion, and the unexpected success of gender quotas in France can be expected as the normative and legal ground shifted once the first parity reform was adopted. However, adoption does not automatically entail widespread diffusion of gender quotas to other domains. In fact, while many countries have adopted electoral quotas, few have witnessed such an extensive diffusion of this mechanism 
in public policy. This diffusion can mostly be explained by the institutional entrenchment of parity in successive WPAs devoted to the issue, first the Observatory and then the HCEfh. Each institution acted as an efficient support structure, providing expertise, prospective knowledge and vehement criticism of attempts at backpedalling political parity through electoral reforms. In a typical policy transfer process, crucial entrepreneurs in those structures, and the simplicity of the tool to be transferred, contributed to the diffusion of quotas from electoral politics to other domains of decision-making. Hence, while literature on WPAs has shown that they can relay women's movements claims (or water them down), and prevent retrenchment of women's rights, the French case shows that, under the leadership of key political players, they can act autonomously to entrench and expand gender quotas.

\section{Acknowledgements}

I thank the participants to the workshop on "Legal mobilization around gender quotas in Europe" held at the European University Institute in September 2014 for their feedbacks and comments on this paper.

\section{Disclosure statement}

No potential conflict of interest was reported by the author.

\section{Notes}

1. On the French idiosyncratic "Republican" opposition to gender quotas, see Bereni and Lépinard (2004), Scott (2005), Lépinard (2007), Lépinard and Mazur (2009), on opposition to gendered policies see Mazur (2001), and on the related opposition to group recognition and affirmative action policies see for example Calvès 2002 and Sabbagh and Peer (2008).

2. The Vallaud-Belkacem bill on 'real equality' adopted on 23 July 2014.

3. Its detractors referred to these measures at the time (and still today) as 'positive discrimination' in order to discredit attempts at implementing positive action measures in favor of any group.

4. Several scholars have analyzed the first rounds of gender quotas implementation in French politics and concluded that they were not as efficient as was expected (see Achin et al. 2007 and for an updated and more optimist assessment, see Murray 2012). However, it is beyond the scope of this paper to evaluate gender quota's impact in terms of bringing concrete gender equality and whether or not they constitute yet another form of symbolic reform in France (see Mazur 1996).

5. Decision no. 82146 DC 18 November 1982.

6. For a review of the research on the parity reform, see Bereni $(2015,13-14)$.

7. Constitutional Law no. 99-569 8 July 1999 relative à l'égalité entre les femmes et les hommes.

8. Law no. 2000-493 6 June 2000 and Law no. 2000-641 10 July 2000.

9. Right-wing deputies tried to curtail every innovation introduced by the reform, especially electoral reforms, with the tacit agreement of many left-wing deputies. For example, despite intense controversy the attempt to implement parity in cities over 2500 inhabitants did not pass, and parity was implemented only in cities over 3500 inhabitants in which elections follow a closed proportional list system.

10. This bureaucratic structure created in 1985 is always affiliated to a broader ministry (such as social affairs) or with a specific political leadership such as a minister or an under-secretary of State depending on the government in power, socialists tending to provide women's rights with a specific ministerial portfolio and right-wing governments tending to subsume it under social affairs.

11. Law no. 2003-697 30 July 2003.

12. Law no. 2003-327 11 April 2003.

13. Law no. 2007-128 31 January 2007.

14. Observatoire de la Parité entre les femmes et les hommes, impact study 2014, accessed online at http:// www.haut-conseil-egalite.gouv.fr/IMG/pdf/OPFH_RT2014_projectionsratios.pdf.

15. Starting in 2002, after each election cycle, the Observatory issued reports on the implementation of parity, and for each parliamentary initiative to reform the electoral system, the parliamentary 
delegations for women's rights as well as the Observatory issued reports indicating the potential effects of those reforms on women's equal access to political office. See http://www.haut-conseil-egalite.gouv. $\mathrm{fr} /$ parite/rapports-institutionnels-40/

16. Law no. 2013-403 17 May 2013.

17. Law no. 2013-702 2 August 2013.

18. Organic Law 14 February 2014.

19. Marie-Jo Zimmermann, who headed the Observatory from 2002 to 2009, decided that the chairs of the Parliamentary delegations for women's rights in the National Assembly, the Senate and the Social and Economic Council should be systematically members of the Observatory, and in 2011 the relationships between the Observatory and the SDFE were strengthened with a convention to exchange good practices and expertise and make initiatives more visible. During this period no less than 14 deputies and/or senators were members of the Observatory.

$55020 . \quad$ Decree no. 98-922 14 October 1998.

21. The report was co-authored by Milewski and Le Pors.

22. See Report from the law commission no. 2205, 2009, 23.

23. Association des femmes diplômées expertise comptable et administrateurs.

24. Interview of Marie-Jo Zimmermann with the author 11 June 2014.

25. Bill project 2214, registered 24 March 2005.

555 26. Law no. 2006-340 23 March 2006 on equal pay between women and men

27. Decision no. 2006-533 DC 16 March 2006.

28. Famously known for defending the law decriminalizing abortion in France, the "loi Veil" of 1975.

29. Interview of Marie-Jo Zimmermann with the author 11 June 2014.

30. Muguette Dini (UDI right wing party), Senate debates, 18 June 2008, 2926.

31. Although deputies might share with private actors a diversity discourse that emphasizes economic performance (Sénac 2010), it should be noted that the latter strongly opposed the idea of constraining measures to reach this diversity goal.

32. Grésy, Brigitte, Rapport préparatoire à la concertation avec les partenaires sociaux sur l'égalité professionnelle entre les femmes et les hommes, juillet 2009.

33. The 2011 Copé-Zimmermann law implements a two-step quota of $20 \%$ by 2014 and $40 \%$ by 2017 for board members of publicly listed companies, as well as unlisted companies which have more than 500 workers and average revenues or total assets of more than 50 million euros during the last three consecutive years. It also applies to some state-owned companies. Boards with member appointments that do not respect the quota are considered null and board members' benefits can be suspended.

34. Report from the law commission no. 2205, 2009, 30.

35. Law no. 2012-347 12 March 2012.

36. 'Fioraso' Law of 22 July 2013.

37. Law of 17 May 2013 reforming the electoral system for departmental elections, law of 2 August 2013 reforming the Senate's elections.

570 38. Although still minimalist: now three full-time persons are employed rather than the two of the Observatory. The members are more numerous, over 70, when the Observatory had less than 40 .

39. Circular from the Prime Minister, 23 August 2012 "relative à la prise en compte dans la préparation des textes législatifs et réglementaires de leur impact en termes d'égalité entre les femmes et les hommes."

40. Decree no. 2013-8 3 January 2013.

41. Avis no. 2013-0514-PAR-002.

575 42. Law no. 2013-660 22 July 2013 on higher education and research.

43. Impact Study, NOR: DFEX1313602L/Bleue-1, 1 July 2014. Law 2014-873 of 4 August 2014.

44. Interview with Caroline Ressot, 11 June 2014.

45. Interview with Caroline Ressot, 11 June 2014, p. 51.

46. Haut Conseil à l'Egalité entre les femmes et les hommes, Avis sur le projet de loi pour l'égalité entre les femmes et les hommes, Avis no. 2013-0912-HCE-007, 49.

\section{References}

Achin, Catherine, Lucie Bargel, Delphine Dulong, and Eric Fassin. 2007. Sexes, genre et politique. Paris: Economica.

Baldez, Lisa. 2004. "Elected Bodies: The Gender Quota Law for Legislative Candidates in Mexico." Legislative Studies Quarterly 29 (2): 231-58. 
Baudino, Claudie. 2005. "Gendering the Republican System: Debates on Women's Political Representation in France." In State Feminism and Political Representation, edited by Joni Lovenduski, 85-105. Cambridge: Cambridge University Press.

Bereni, Laure. 2004. "Le mouvement français pour la parité et l'Europe." In Les usages de l'Europe: acteurs et transformations européennes, edited by Sophie Jaequot and Cornelia Woll, 33 54. Paris: L'harmattan.

Bereni, Laure. 2009. "Faire de la diversité une richesse pour l'entreprise." Raisons Politiques 35 (3): 87-105.

Bereni, Laure. 2015. La bataille de la parité. Mobilisations pour la féminisation du pouvoir. Paris: Economica.

Bereni, Laure, and Eléonore Lépinard. 2004. “Les femmes ne sont pas une catégorie’ les stratégies de légitimation de la parité en France." Revue française de science politique 54 (1): 71-98.

Bereni, Laure, and Anne Revillard. 2007. "Des quotas à la parité: 'féminisme d'Etat' et representation politique (1974-2007)." Genèses 2 (67): 5-23.

Calvès, Gwénaële. 2002. "Il n’y pas de race ici." Critique internationale 4 (17): 173-186.

Caul, Miki. 2001. "Political Parties and the Adoption of Candidate Gender Quotas: A Cross-National Analysis." The Journal of Politics 63 (4): 1214-29.

Dauhpin, Sandrine, and Jocelyne Praud. 2002. "Debating and Implementing Gender Parity in French Politics." Modern \& Contemporary France 10 (1): 5-11.

Dolowitz, David, and David Marsh. 1996. "Who Learns What from Whom: A Review of the Policy Transfer Literature." Political Studies 44: 343-357.

Dolowitz, David, and David Marsh. 2000. "Learning from Abroad: the Role of Policy Transfer in Contemporary Policy-Making." Governance 13 (1): 5-23.

Epp, Charles. 1998. The Rights Revolution. Chicago: Chicago University Press.

Franceschet, Susan, Mona Lena Krook, and Jennifer M. Piscopo. 2011. The Impact of Gender Quotas. Oxford: Oxford University Press.

Franceschet, Susan, and Jennifer M. Piscopo. 2008. "Gender Quotas and Women's Substantive Representation: Lessons from Argentina." Politics \& Gender 4: 393-425.

Franceschet, Susan, and Jennifer M. Piscopo. 2013. "Equality, Democracy, and the Broadening and Deepening of Gender Quotas." Politics and Gender 9 (3): 310-316.

Gilardi, Fabrizio. 2010. "Who Learns from What in Policy Diffusion Processes?" American Journal of Political Science 54 (3): 650-666.

Giraud, Isabelle, and Jane Jenson. 2001. “Constitutionalizing Equal Access: High Hopes, Dashes Hopes?” In Has Liberalism Failed Women? Assuring Equal Representation in Europe and the United States, edited by Jytte Klausen and Charles S. Maier, 69-88. New York: Palgrave.

Halimi, Gisèle. 1998. La parité dans la vie politique. Paris: La documentation française.

Holli, Anne-Maria. 2011. "Transforming Local Politics? The Impact of Gender Quotas in Finland." In Women and Representation in Local Government. International Case Studies, edited by B. Pini and P. MacDonald: New York: Routledge.

Htun, Mala, and Mark P. Jones. 2002. "Engendering the Right to Participate in Decision-Making: Electoral Quotas and Women's Leadership in Latin American." In Gender and the Polities of Rights and Demoeracy in Latin America, edited by Nikki-Craske and Maxine Molyneux, 32 56. New York: Palgrave.

Keck, Margaret, and Kathryn Sikkink. 1998. Activists Beyond Borders: Advocacy Networks in International Politics. Ithaca, NY: Cornell University Press.

Krook, Mona Lena. 2006. "Reforming Representation: The Diffusion of Candidate Gender Quotas Worldwide." Politics \& Gender 2 (3): 303-27.

Krook, Mona Lena. 2009. Quotas for Women in Politics. Gender and Candidate Selection. Reform Worldwide. New York: Oxford University Press.

Krook, Mona Lena, Joni Lovenduski, and Judith Squires. 2006. "Western Europe, North America, Australia and New Zealand: Gender Quotas in the Context of Citizenship Models." In Women, Quotas, and Politics, edited by Drude Dahlerup, 194-221. New York: Routledge.

Lépinard, Eléonore. 2006

Lépinard, Eléonore. 2007

Lépinard, Eléonore. 2013

Lépinard, Eléonore, and Amy Mazur. 2009. "Republican Universalism Faces the Feminist Challenge: The Continuing Struggle for Gender Equality." In The French Fifth Republic at Fifty. Beyond Stereotypes, edited by S. Brouard, A. M. Appleton, and A. G. Mazur, 247-266. New York: Palgrave Macmillan.

Lovenduski, Joni, ed. 2005. State Feminism and Political Representation. Cambridge: Cambridge University Press. 
Maggetti, Martino, and Fabrizio Gilardi. 2015. "Problems (and Solutions) in the Measurement of Policy Diffusion Mechanisms." Journal of Public Policy.

Mazur, Amy G. 1996. Gender bias and the State: Symbolic Reform at Work in Fifth Republic France. Pittsburgh: University of Pittsburgh Press.

Mazur, Amy G. 2001. "Republican Universalism Resists State Feminist Approaches to Gendered Equality in France." In State Feminism, Women's Movements, and Job Training: Making Democracies Work in the Global Economy, edited by A. G. Mazur, 155-82. New York: Routledge.

McBride, Dorothy E., and Amy G. Mazur. 2010. The Politics of State Feminism. Philadelphia: Temple University Press.

Meier, Petra. 2004. "The Mutual Contagion Effect of Legal and Party Quotas: A Belgian Perspective." Party Politics 10 (5): 583-600.

Meier, Petra. 2012. "From Laggard to Leader: Explaining the Belgian Gender Quotas and Parity Clause." West European Politics 35 (2): 362-379.

Meier, Petra. 2014. "Quotas for Advisory Committees, Business and Politics: Just More of the Same?" International Political Science Review 35 (1): 106-118.

Murray, Rainbow. 2010. Parties, Gender Quotas and Candidate Selection in France. Basingstoke: Palgrave Macmillan.

Murray, Rainbow. 2012. "Parity in France: A ‘Dual-Track’ Solution to Women's under-Representation.” 35 (2): 343-361.

Murray, Rainbow, Mona Lena Krook, and Katherine A. R. Opello. 2012. "Why are Gender Quotas Adopted? Party Pragmatism and Parity in France." Political Research Quarterly 65 (3): 529-543.

Oliveira, Alvaro, and Michal Gondek. 2014. "Women on Company boards. An example of positive action in Europe." EUI Working paper series RCAS 2014/34.

Opello, Katherine A. R. 2006. Gender Quotas, Parity Reform and Political Parties in France. Lanham, MD: Lexington Books.

Piscopo, Jennifer. 2015. "States as Gender Equality Activists: The Evolution of Quota Laws in Latin America." Latin American Politics and Society.

Praud, Jocelyne. 2012. "Introduction: Gender Parity and Quotas in European Politics." West European Politics 35 (2): 286-300.

Ressot, Caroline. 2013. "L'Observatoire de la parité." In Egalité-Parité, une nouvelle approche de la démocratie, edited by Wavier Bioy and Marie-Laure Pages. Toulouse: Presses de l'Université Toulouse 1/LGDJ.

Rodriguez Ruiz, Blanca, and Ruth Rubio Marin. 2008. "The Gender of Representation: On Democracy, Equality, and Parity." International Journal of Constitutional Law 6 (2): 287-316.

Rosenblum, Darren. 2006. "Parity/Disparity. Electoral Gender Equality on the Tightrope of Liberal Constitutional Traditions." University of California Davis Law Review 39: 1119-1189.

Sabbagh, Daniel, and Shanney Peer. 2008. "French Color Blindness in Perspective. The Controversy over 'Statistiques Ethniques'." French Politics, Culture and Society 26 (1): 1-6.

Scott, Joan W. 2005. Parité! Sexual Equality and the Crisis of French Universalism. Chicago: University of Chicago Press.

Sénac, Réjane. 2010. "De la parité à la diversité: entre Deuxième sexe et discrimination seconde.” Modern \& Contemporary France 18 (4): 431-444.

Stetson, Dorothy McBride, and Amy Mazur, eds. 1995. Comparative State Feminism. Thousand Oaks: Sage.

Stetson, Dorothy McBride, and Amy Mazur. 2000. "Women's Movements and the State: Job-Training Policy in France and the U.S." Political Research Quarterly 53 (3): 597-623. 